\title{
TINGKAT SOLVABILITAS PERUSAHAAN ASURANSI JIWA SYARIAH DI INDONESIA
}

\author{
SOLVABILITY LEVEL OF SHARIA LIFE INSURANCE COMPANIES IN \\ INDONESIA \\ Nur Wachidah Yulianti* \\ Program Studi Akuntansi, Fakultas Ekonomi dan Bisnis UIN Syarif Hidayatullah Jakarta \\ Jl. Ibnu Sina IV, Ciputat, Tangerang Selatan, Banten 15419 \\ wachi@uinjkt.ac.id
}

\begin{abstract}
This study aims to look at the mean difference of solvability level of tabarru' fund of sharia life insurance companies in Indonesia. The population of this research were full fledge life insurance companies from 2014 to 2019. This research was tested data through one way analysis of variance (ANOVA) test. One way ANOVA test result shown that there is a significant mean difference between sharia life insurance companies in Indonesia at the solvability level of tabarru' funds.
\end{abstract}

Keywords: mean difference, ANOVA, life insurance, solvability

\begin{abstract}
ABSTRAK
Penelitian ini bertujuan untuk melihat perbedaan rata-rata (mean difference) tingkat solvabilitas dana tabarru' pada perusahaan asuransi jiwa syariah di Indonesia. Populasi penelitian ini adalah perusahaan asuransi jiwa (full fledge) dari tahun 2014 sampai dengan tahun 2019. Data dalam penelitian ini diuji melalui one way Analysis of Variance (ANOVA). Hasil uji one way ANOVA menunjukkan bahwa terdapat perbedaan yang signifikan antara perusahaan asuransi jiwa syariah di Indonesia pada tingkat solvabilitas dana tabarru”.
\end{abstract}

Kata kunci: mean difference, ANOVA, asuransi jiwa, solvabilitas

*Corresponding author

Email:wachi@uinjkt.ac.id

DOI: https://doi.org/10.33369/j.akuntansi.10.3.213-222

\section{PENDAHULUAN}

Dalam beberapa tahun terakhir ini, tepatnya dari tahun 2011 hingga 2014, perkembangan industri perasuransian di Indonesia, mengalami pertumbuhan. Hal ini dibuktikan dengan pertumbuhan aset industri asuransi konvensional yang rata-rata mencapai lebih dari $16 \%$. Selain itu, nilai investasi dan premi asuransi juga mengalami pertumbuhan dengan nilai peningkatan rata-rata sebesar $14,4 \%$ dan juga $21,0 \%$, Bahkan pada tahun 2015, tepatnya hingga akhir September 2015, tercatat nilai aset dan investasi asuransi konvesional menunjukkan angka hampir mencapai Rp765,6 Triliun dan Rp608,6 Triliun. Jika dibandingkan dengan posisi yang sama di tahun 2014, maka aset industri asuransi mengalami pertumbuhan sebesar $1,36 \%$ (Cermati.com, 2016).

Pertumbuhan premi asuransi konvensional juga tidak kalah pesatnya. Tercatat, hingga September 2015, peningkatan premi asuransi cukup memuaskan yakni sebesar $17,1 \%$. Jika dibandingkan dengan pertumbuhan pada Agustus 2015, maka jumlah ini meningkat sebesar 
11,9\% dari periode yang sama pada tahun sebelumnya. Diketahui bahwa peningkatan premi ini paling tinggi disumbang oleh perusahaan asuransi jiwa, asuransi sosial dan asuransi umum (Cermati.com, 2016).

Asuransi jiwa bagi sebagian masyarakat Indonesia merupakan hal yang mendasar. Asuransi jiwa merupakan proteksi masyarakat terhadap risiko yang mungkin menimpa diri mereka sendiri atau keluarga mereka. Seiring dengan kepedulian masyarakat Indonesia terhadap risiko tersebut maka tak pelak, pertumbuhan usaha asuransi jiwa di Indonesia dapat dikatakan cukup pesat. Tercatat, tingkat rasio jumlah dana pada perusahaan asuransi jiwa konvensional terhadap produk domestik bruto di tahun 2010 sbesar 1,00\%, setelah itu pada tahun 2015, rasio tersebut naik menjadi $1,28 \%$. Di samping itu pengeluaran rata-rata penduduk Indonesia untuk membayar premi asuransi dalam setahun mengalami peningkatan menjadi 42,7\% dari yang sebelumnya di tahun 2010 sebesar 30,9\%. Secara agregat, dari tahun 2014 sampai dengan 2015, tingkat pertumbuhan asuransi jiwa di Indonesia mencapai 30\% sampai dengan 35\% (Ananta, 2019).

Namun pada tahun 2017 hingga pertengahan 2019 lalu, geliat pertumbuhan asuransi jiwa konvensional di Indonesia cenderung menurun. Banyak faktor yang ditengarai menjadi penyebab penurunan tersebut. Hilangnya kepercayaan masyarakat karena gagal bayar klaim nasabah asuransi Jiwasraya dan Asuransi Jiwa Bersama (AJB) Bumiputera adalah salah satu penyebabnya. Berdasarkan CNBC Indonesia, hingga September 2019, kerugian yang dialami Jiwasraya sebesar Rp13,74 triliun, ditambah lagi rasio kecukupan modal atau risk based capital (RBC) per September 2019 juga anjlok ke angka minus 805\%. Padahal, berdasarkan Peraturan Otoritas Jasa Keuangan (OJK) No. 71/POJK.O5/2015 tentang Kesehatan Keuangan Perusahaan Asuransi dan Reasuransi, RBC perusahaan asuransi minimal sebesar 120\%. Oleh karena itu, saat ini Jiwasraya sedang menghadapi gugatan dari para nasabahnya (Asmara, 2019). Asuransi Jiwa Bersama (AJB) Bumiputera pun menghadapi hal yang sama. Hingga akhir Januari 2018, total klain jatuh tempo atau outstanding yang belum dibayarkan kepada nasabahnya sudah mencapai angka Rp2,7 triliun dan bahkan di Jawa Barat, ada 19.000 nasabah yang belum dibayarkan klaimnya (Kompas.com, 2019).

Di saat perusahaan asuransi jiwa konvensional sedang lesu karena kasus Jiwasraya dan AJB Bumiputera, justru pada lima bulan pertama tahun 2018, industri asuransi jiwa syariah memperlihatkan tren positif. OJK mencatat, industri asuransi jiwa syariah hingga Mei 2018, telah membukukan preminya sebesar Rp5,81 triliun. Jika dibandingkan dengan Mei 2017, maka jumlah tersebut naik 40,95\% secara year on year (yoy) (kontan.co.id, 2018).

Secara global, menurut data OJK, pada tahun 2018 aset asuransi syariah mencapai Rp41,96 triliun. Asuransi jiwa syariah memberikan andil sebesar 34,47 triliun, asuransi umum syariah sebesar Rp5,62 triliun dan reasuransi syariah Rp1,86 triliun (CNN Indonesia, 2019). Sedangkan dari sisi "pemain" dalam industri asuransi jiwa syariah, berdasarkan data OJK, per tanggal 19 Februari 2016 tercatat, terdapat 5 perusahaan asuransi jiwa syariah (full fledge) dan 19 unit usaha syariah perusahaan asuransi jiwa di Indonesia (OJK, 2016).

Usaha asuransi jiwa syariah tidaklah sama dengan usaha asuransi jiwa konvensional. Pada usaha asuransi jiwa syariah, polis yang ditawarkan kepada nasabah harus berlandaskan pada prinsip syariah yaitu wajib mengandung Akad Tabarru' dan Akad Tijarah. Akad Tabarru' digunakan di antara sesama peserta. Setiap peserta memberikan hibah berupa kontribusi (premi) melalui dana tabarru' yang akan digunakan untuk menolong peserta lain yang terkena musibah. Perusahaan asuransi berfungsi sebagai pengelola dana tersebut. Dana tabarru' diinvestasikan pada instrumen keuangan yang sesuai dengan prinsip syariah. Dana tabarru' bukanlah dana perusahaan, sehingga di dalam perusahaan asuransi jiwa syariah, dana tabarru' dikelola secara terpisah dengan dana perusahaan.

Kendati demikian, tidaklah menutup kemungkinan perusahaan asuransi jiwa syariah tersebut mengalami risiko insolvency seperti perusahaan asuransi Jiwasraya dan AJB 
bumiputera. Agar terhindar dari risiko tersebut, perusahaan asuransi jiwa syariah harus menjaga solvabilitas mereka, terutama pada rasio solvabilitas dana tabarru' karena dana tabarru' adalah dana peserta asuransi yang sewaktu-waktu akan diminta dalam bentuk klaim asuransi.

Bagi perusahaan umum, solvabilitas didefinisikan sebagai kemampuan perusahaan untuk melunasi semua kewajiban perusahaan baik jangka pendek maupun jangka panjang. Namun bagi perusahaan asuransi, definisi solvabilitas harus diatur oleh regulator, karena menyangkut kekayaan masyarakat umum (Bakrie, 2015). Menurut Peraturan OJK (POJK) No.71/PJOK.05/2016 tentang Kesehatan Keuangan Perusahaan Asuransi dan Reasuransi, dan Peraturan OJK (POJK) No.72/PJOK.05/2016 tentang Kesehatan Keuangan Perusahaan Asuransi dan Reasuransi dengan prinsip syariah, tingkat solvabilitas adalah jumlah aset yang diperkenankan dikurangi dengan jumlah liabilitas dan menurut POJK itu juga tingkat solvabilitas menjadi ukuran kesehatan sebuah perusahaan asuransi baik konvensional maupun syariah.

Penelitian yang mengulas mengenai solvabilitas perusahaan asuransi memang sudah banyak dilakukan. Biasanya peneliti menjadikan solvabilitas sebagai variabel independen atas variabel dependen tertentu, misalnya Ilhama \& Abdullah (2018) meneliti tentang pengaruh solvabilitas terhadap premi bruto asuransi di Indonesia. Hasil penelitiannya menunjukan bahwa solvabilitas berpengaruh terhadap premi bruto asuransi. Namun ada juga peneliti yang menjadikan solvabilitas sebagai dependen variabel untuk variabel independen tertentu, misalnya Ambarwati \& Hasib (2018), hasil penelitiannya menunjukan bahwa ukuran perusahaan, hasil investasi dan profitabilitas secara simultan berpengaruh terhadap tingkat solvabilitas perusahaan asuransi jiwa syariah. Utami \& Khoiruddin (2016) yang hasil penelitiannya menunjukan bahwa rasio beban berpengaruh signifikan terhadap tingkat solvabilitas, sedangkan rasio likuiditas, retensi sendiri dan ukuran perusahaan tidak berpengaruh terhadap tingkat solvabilitas perusahaan asuransi.

Namun berdasarkan penelusuran penulis, sejauh ini belum ada penelitian yang melihat rata-rata tingkat solvabilitas dana tabarru' perusahaan asuransi jiwa syariah di Indonesia. Dengan demikian, tujuan penelitian ini adalah untuk menguji perbedaan tingkat solvabilitas dana tabarru' di antara perusahaan asuransi jiwa syariah yang ada di Indonesia. Penelitian ini diharapkan dapat menyajikan informasi kepada para stakeholders perusahaan asuransi jiwa syariah terkait tingkat kesehatan masing-masing perusahaan melalui perbandingan tingkat solvabilitas dana tabarru' perusahaan asuransi tersebut.

\section{KERANGKA TEORITIS DAN HIPOTESIS}

\section{Teori Keagenan (Agency Theory)}

Teori agensi adalah teori yang menyebutkan bahwa perusahaan adalah tempat atau intersection point bagi banyak kontrak yang terjadi atau nexus of contract antara manajemen sebagai agent dengan principal seperti pemilik, pelanggan, karyawan dan pemerintah. Agent mempunyai kontrak untuk mengelola usaha dan membuat keputusan yang terbaik untuk kepentingan principal. Di dalam teori agensi, agent mengetahui dan memiliki semua informasi yang ada di dalam perusahaan sedangkan principal tidak demikian. Oleh karena itu, di dalam teori agensi seringkali terjadi asymetri information dan bahkan menimbulkan masalah keagenan (agency problem).

Laporan keuangan yang disusun dan disampaikan oleh agent atau manajemen dapat meminimalisir asymetri information tersebut. Informasi yang terdapat dalam laporan keuangan dapat menjadi alat kontrol bagi principal mengenai kinerja agent dan going concern perusahaan. Going concern perusahaan dapat tercermin dari tingkat kesehatannya. Tingkat kesehatan tersebut dapat diukur melalui rasio-rasio keuangan yang terdapat dalam laporan keuangan. 
Bagi perusahaan asuransi jiwa baik konvensional maupun syariah, tingkat solvabilitas merupakan tolak ukur kesehatan perusahaan, sehingga manajemen akan menginformasikannya kepada para principal di dalam laporan keuangan yang mereka terbitkan, dan ini merupakan salah satu solusi meminimalisir asymetri information dan bisa dijadikan alat kontrol bagi principal.

\section{Usaha dan Perusahaan Asuransi Jiwa Syariah}

Berdasarkan Undang-undang (UU) No 40 Tahun 2014 tentang perasuransian (Republik Indonesia, 2014), yang dimaksud Usaha Asuransi Jiwa Syariah adalah usaha pengelolaan risiko berdasarkan prinsip syariah guna saling tolong menolong dan melindungi dengan memberikan pembayaran yang didasarkan pada meninggal atau hidupnya peserta, atau pembayaran lain kepada peserta atau pihak lain yang berhak pada waktu tertentu yang diatur dalam perjanjian, yang besarnya telah ditetapkan dan/atau didasarkan pada hasil pengelolaan dana. Perusahaan asuransi jiwa syariah hanya dapat menyelenggarakan Usaha Asuransi Jiwa Syariah termasuk lini usaha anuitas berdasarkan Prinsip Syariah, lini usaha asuransi kesehatan berdasarkan Prinsip Syariah, dan lini usaha asuransi kecelakaan diri berdasarkan Prinsip Syariah. Yang dimaksud dengan prinsip syariah adalah prinsip dengan akad tolong-menolong (ta'awuni) dan saling melindungi (takafuli) di antara para Peserta melalui pembentukan kumpulan dana (Dana Tabarru') yang dikelola untuk menghadapi risiko tertentu.

\section{Tingkat Solvabilitas Perusahaan Asuransi berbasis syariah}

Secara umum solvabilitas merupakan salah satu rasio keuangan yang menggambarkan apakah sebuah perusahaan dapat melunasi seluruh kewajibannya, baik jangka pendek maupun jangka panjang (Harahap, 2013). Selain itu, solvabilitas juga merupakan rasio yang dapat digunakan untuk mengukur sejauh mana aktiva perusahaan dibiayai oleh utang (Kasmir, 2013).

Bagi perusahaan asuransi yang berbasis syariah, rasio solvabilitas diatur melalui Peraturan Otoritas Jasa Keuangan (POJK) Nomor 72/POJK.05/2016 tentang Kesehatan Keuangan Perusahaan Asuransi dan Perusahaan Reasuransi dengan Prinsip Syariah. Berdasarkan pasal 1 poin 23 regulasi tersebut, dinyatakan bahwa tingkat solvabilitas dana tabarru' adalah selisih antara jumlah aset yang diperkenankan dari dana tabarru' dikurangi dengan liabilitas dari pengelolaan dana tabarru' perusahaan asuransi jiwa merupakan selisih atas aset yang dperkenankan dengan total liabilitas. Selanjutnya, masih dalam regulasi yang sama, pada pasal 10 dinyatakan bahwa perusahaan asuransi syariah wajib memenuhi tingkat solvabilitas dana tabarru' paling rendah sebesar 100\% (seratus persen) dari Dana Tabarru' Minimum Berbasis Risiko (DTMBR). DTMBR adalah jumlah dana yang dibutuhkan untuk mengantisipasi risiko kerugian yang mungkin timbul sebagai akibat dari deviasi dalam pengelolaan aset dan likuiditas dari dana tabarru'. Hal inilah yang disebut sebagai Risk Based Capital (RBC) dalam perusahaan asuransi yang berprinsip syariah. RBC dapat dilihat dari tingkat pencapaian rasio solvabilitas atau dengan membandingkan tingkat solvabilitas dengan batas minimum tingkat solvabilitas yang ditetapkan pada dana tabarru'.

\section{Pengembangan Hipotesis}

Merujuk pada paparan yang telah dijelaskan sebelumnya, maka hipotesis yang dikembangkan guna menjawab pertanyaan penelitian di atas adalah:

$\mathrm{H}_{0}$ : tidak terdapat perbedaan rata-rata tingkat solvabilitas dana tabarru' di antara perusahaan asuransi jiwa syariah di Indonesia

$\mathrm{H}_{\mathrm{I}}$ : terdapat perbedaan rata-rata tingkat solvabilitas dana tabarru' di antara perusahaan asuransi jiwa syariah di Indonesia 


\section{METODE PENELITIAN}

Guna menjawab pertanyaan penelitian yang telah diuraikan sebelumnya, maka digunakan uji parametrik One Way Analysis of Variance (ANOVA). Teknik ini digunakan karena penelitian ini menguji perbedaan rata-rata tingkat solvabilitas dana tabarru' dari 5 perusahaan asuransi jiwa syariah (full fledge) yang ada di Indonesia dari tahun 2014 sampai dengan tahun 2019. Dengan alpha $\alpha$ 5\%, maka keputusan untuk menerima $\mathrm{H}_{0}$ apabila $p$ value $>0,05$. Syarat dilakukannya uji ANOVA adalah semua data harus terdistribusi normal. Pengujian normalitas data menggunakan uji Shapiro Wilk karena sampel dalam penelitian ini kurang dari $50(\mathrm{n}=30)$. Dasar pengambilan keputusannya apabila nilai sig $>0,05$ maka data terdistribusi normal. Prinsip One Way Analysis of Variance (ANOVA) adalah melakukan analisis variabilitas data menjadi dua sumber variasi yaitu variasi di dalam kelompok (within) dan variasi antar kelompok (between). Bila nilai perbandingan variasi within dan between sama yaitu mendekati angka satu, maka berarti tidak ada perbedaan efek dari intervensi yang dilakukan, dengan kata lain nilai mean yang dibandingkan tidak ada perbedaan. Sebaliknya bila variasi antar kelompok lebih besar dari variasi di dalam kelompok, artinya intervensi tersebut memberikan efek yang berbeda, dengan kata lain nilai mean yang dibandingkan menunjukkan adanya perbedaan (Hidayat, 2017).

Sebelum dilakukan uji ANOVA terlebih dahulu akan dilakukan uji homogeneity of variance. Uji ini dilakukan untuk melihat kesamaan varian dari data. Setelah dilakukan uji homogeneity of variance, maka dapat dilakukan uji ANOVA yang berfungsi untuk melihat ada tidaknya perbedaan rata-rata (mean difference) tingkat solvabilitas dana tabarru' dari perusahaan asuransi jiwa syariah di Indonesia. Jika terdapat perbedaan maka selanjutnya dilakukan uji post hoc test yang terdiri dari dua jenis yaitu uji Bonferroni dan uji Tukey HSD (Ghozali, 2018) serta uji Gomes-Howell. Apabila varian data homogen, maka uji Bonferroni dan uji Tukey HSD yang digunakan, namun apabila varian data tidak homogen, maka digunakan uji Gomes-Howell (Hidayat, 2017).

\section{HASIL DAN PEMBAHASAN}

Populasi dalam penelitian ini adalah perusahaan asuransi jiwa syariah yang full fledge yaitu sebanyak 5 perusahaan sebagaimana tabel 1 berikut.

Tabel 1. Daftar perusahaan asuransi jiwa syariah di Indonesia (full fledge)

\begin{tabular}{clc}
\hline No & \multicolumn{1}{c}{ Nama Perusahaan } & Singkatan \\
\hline 1. & PT Asuransi Jiwa Syariah Al Amin & AMN \\
\hline 2. & PT Asuransi Takaful Keluarga & TKF \\
\hline 3. & PT Asuransi Jiwa Syariah Amanahjiwa Giri Artha & AGA \\
\hline 4. & PT Asuransi Jiwa Syariah Jasa Mitra Abadi & JMA \\
\hline 5. & PT Asuransi Syariah Keluarga Indonesia & SKI
\end{tabular}

Sumber: Otoritas Jasa Keuangan, 19 Februari 2016

Penelitian ini menggunakan data sekunder berupa data tingkat solvabilitas dana tabarru' dari tahun 2014 sampai dengan tahun 2019 yang diambil dari laporan keuangan perusahaan di atas yang terdapat dalam website perusahaan tersebut. Dengan demikian populasi dalam penelitian ini sebanyak 30 sebagaimana dalam tabel berikut: 
TINGKAT SOLVABILITAS PERUSAHAAN ASURANSI JIWA SYARIAH DI INDONESIA

Nur Wachidah Yulianti

Tabel 2. Data rasio pencapaaian solvabilitas dana tabarru' perusahaan asuransi jiwa syariah

\begin{tabular}{|c|c|c|c|}
\hline No & Tahun & Nama Perusahaan & Rasio Pencapaian Solvabilitas Dana Tabarru' \\
\hline 1 & 2014 & AMN & 1,128 \\
\hline 2 & 2014 & TKF & 1,057 \\
\hline 3 & 2014 & AGA & 1,164 \\
\hline 4 & 2014 & JMA & 0,000 \\
\hline 5 & 2014 & SKI & 0,000 \\
\hline 6 & 2015 & AMN & 1,434 \\
\hline 7 & 2015 & TKF & 1,407 \\
\hline 8 & 2015 & AGA & 1,241 \\
\hline 9 & 2015 & JMA & 0,830 \\
\hline 10 & 2015 & SKI & 0,000 \\
\hline 11 & 2016 & $\mathrm{AMN}$ & 2,514 \\
\hline 12 & 2016 & TKF & 1,730 \\
\hline 13 & 2016 & AGA & 1,545 \\
\hline 14 & 2016 & JMA & 0,500 \\
\hline 15 & 2016 & SKI & 0,375 \\
\hline 16 & 2017 & AMN & 3,971 \\
\hline 17 & 2017 & TKF & 1,748 \\
\hline 18 & 2017 & AGA & 1,414 \\
\hline 19 & 2017 & JMA & 0,800 \\
\hline 20 & 2017 & SKI & 0,822 \\
\hline 21 & 2018 & AMN & 1,951 \\
\hline 22 & 2018 & TKF & 3,075 \\
\hline 23 & 2018 & AGA & 1,911 \\
\hline 24 & 2018 & JMA & 67,147 \\
\hline 25 & 2018 & SKI & 1,284 \\
\hline 26 & 2019 & AMN & 1,599 \\
\hline 27 & 2019 & TKF & 3,030 \\
\hline 28 & 2019 & AGA & 2,791 \\
\hline 29 & 2019 & JMA & 6,120 \\
\hline 30 & 2019 & SKI & 1,979 \\
\hline
\end{tabular}

Sumber: Data diolah

Tabel berikut ini merupakan hasil uji deskriptif atas rasio solvabilitas dana tabarru' perusahaan asuransi jiwa syariah di Indonesia dari tahun 2014 sampai dengan tahun 2019.

Tabel 3. Hasil Uji Deskriptif Statistik Rasio Solvabilitas Dana Tabarru'

\begin{tabular}{ccccc}
\hline Nama Perusahaan & N & Nilai Rata-rata & Nilai Minimum $^{*}$ & Nilai Maksimum $\left.^{*}\right)$ \\
\hline AMN & 6 & 2,0995 & 1,13 & 3,97 \\
\hline TKF & 6 & 2,0078 & 1,06 & 3,08 \\
\hline AGA & 6 & 1,6777 & 1,16 & 2,79 \\
\hline JMA & 6 & 12,5662 & 0,00 & 67,15 \\
\hline SKI & 6 & 0,7433 & 0,00 & 1,98 \\
\hline
\end{tabular}

Sumber: Data hasil SPSS diolah

Berdasarkan tabel hasil uji deskriptif statistik, diketahui bahwa PT JMA dalam periode tahun 2014 sampai dengan tahun 2019 memiliki nilai rata-rata rasio solvabilitas dana tabarru' 
yang tertinggi di antara perusahaan asuransi jiwa syariah yang lainnya. Oleh karena nilai ratarata JMA sangat ekstrem, maka untuk ke tahap selanjutnya dalam penelitian ini JMA tidak dimasukan lagi sebagai sampel.

Uji normalitas data adalah syarat yang harus dipenuhi untuk dilakukannya Uji ANOVA. Uji normalitas data dalam penelitian ini dilakukan dengan uji Shapiro Wilk karena sampel data kurang dari 50. Dasar keputusan uji Shapiro Wilk adalah jika nilai signifikansi > 0,05 maka data terdistribusi normal. Hasil uji Shapiro Wilk sebagaimana terlihat dalam tabel 4.

Tabel 4. Hasil Uji Normalitas Shapiro Wilk

\begin{tabular}{cccc}
\hline Nama Perusahaan & df & Nilai Statistik & Nilai Signifikansi \\
\hline AMN & 6 & 0,877 & $\left.0,254^{*}\right)$ \\
\hline TKF & 6 & 0,857 & $\left.0,179^{*}\right)$ \\
\hline AGA & 6 & 0,845 & $0,145^{*}$ \\
\hline SKI & 6 & 0,912 & $0,450^{*}$ \\
\hline
\end{tabular}

${ }^{*}$ Signifikan pada alpha 5\%

Sumber: Data hasil SPSS diolah

Terlihat bahwa dalam tabel hasil uji normalitas, semua nilai signifikansi berada berada di atas alpha 5\%. Dengan demikian, dapat disimpulkan bahwa semua data berdistribusi normal.

Oleh karena semua data berdistribusi normal, maka sebelum dilakukan uji one way ANOVA, terlebih dahulu dilakukan uji varians data yang sama (homogeneity of variances). Nilai signifikansi $(p$ value $)>0.05$ menunjukkan kelompok data berasal dari populasi yang memiliki varians yang sama (homogen). Tabel berikut ini merupakan hasil uji homogeneity of variances untuk tingkat solvabilitas dana tabarru'.

Tabel 5. Hasil Uji homogeneity of variances tingkat solvabilitas dana tabarru'

\begin{tabular}{cccc}
\hline & Levene Statistic & Sig $(p$-value $)$ & Keputusan \\
\hline Dana Tabarru' & 0,559 & 0,649 & Varian data homogen \\
\hline
\end{tabular}

Sumber: Data hasil SPSS diolah

Oleh karena nilai Sig ( $p$-value) pada dana tabarru' di atas alpha 5\% $(0,649)$ maka varian data untuk tingkat solvabilitas dana tabarru' adalah homogen.

Untuk dapat melanjutkan uji post hoc, harus dilihat terlebih dahulu apakah ada perbedaan tingkat solvabilitas dana tabarru' perusahaan asuransi jiwa syariah di Indonesia, yang tercermin dari nilai signifikansi ANOVA. Keputusan untuk melihat ada perbedaan dapat dilihat pada nilai signifikasi (Sig) ANOVA. Apabila nilai Sig lebih kecil dari alpha 5\% $(0,05)$, maka $\mathrm{H}_{1}$ diterima yaitu terdapat perbedaan yang signifikan pada tingkat solvabilitas dana tabarru' di antara perusahaan asuransi jiwa syariah di Indonesia dan uji post hoc dapat dilakukan. Namun apabila nilai sig lebih besar dari alpha 5\%, maka $\mathrm{H}_{0}$ diterima yang artinya tidak terdapat perbedaan yang signifikan pada tingkat solvabilitas dana tabarru' perusahaan asuransi jiwa syariah di Indonesia, dan uji post hoc tidak dapat dilanjutkan.

Tabel 6. Hasil Uji ANOVA tingkat solvabilitas dana tabarru’ dan dana perusahaan

\begin{tabular}{lcc}
\hline & Sig & Keputusan \\
\hline Dana Tabarru' & 0,040 & Ada Perbedaan \\
\hline Sumber: Data hasil SPSS diolah & &
\end{tabular}

Hasil uji ANOVA sebagaimana dalam Tabel 6 menunjukkan bahwa nilai sig di bawah alpha 5\% $(0,05)$ yaitu sebesar $0,040(0,040<0,05)$. Artinya, terdapat perbedaan tingkat solvabilitas dana tabarru' di antara perusahaan asuransi jiwa syariah di Indonesia, oleh karena itu uji post hoc dapat dilakukan 
Uji Post Hoc Test terdiri dari uji Bonferroni dan uji Tukey HSD serta uji Gomes-Howell. Apabila varian data homogen, maka uji Bonferroni dan uji Tukey HSD yang digunakan, namun apabila varian data tidak homogen, maka digunakan uji Gomes-Howell. Sebagaimana terlihat dalam tabel 5, dana tabarru' memiliki varian data yang homogen, dengan demikian maka dilakukan uji Bonferroni dan Uji Tukey HSD. Hasil uji tersebut sebagaimana terlihat dalam tabel 7 .

Tabel 7. Hasil Uji Bonferroni

\begin{tabular}{ccccc}
\hline Perusahaan & Terhadap Perusahaan & Mean Difference & Sig & Keputusan \\
\hline AMN & TKF & 0,091 & 1,000 & Tidak terdapat perbedaan \\
\hline & AGA & 0,421 & 1,000 & Tidak terdapat perbedaan \\
\hline TKF & SKI & 1,3617 & 0,063 & Tidak terdapat perbedaan \\
\hline & AMN & $-0,916$ & 1,000 & Tidak terdapat perbedaan \\
\hline AGA & AGA & 0,330 & 1,000 & Tidak terdapat perbedaan \\
\hline & SKI & 1,2645 & 0,095 & Tidak terdapat perbedaan \\
\hline & AMN & $-0,421$ & 1,000 & Tidak terdapat perbedaan \\
\hline SKI & TKF & $-0,330$ & 1,000 & Tidak terdapat perbedaan \\
\hline & SKI & 0,934 & 0,395 & Tidak terdapat perbedaan \\
\hline & AMN & $-1,357$ & 0,063 & Tidak terdapat perbedaan \\
\hline & TKF & $-1,26$ & 0,095 & Tidak terdapat perbedaan \\
\hline
\end{tabular}

Sumber: Data hasil SPSS diolah

Berdasarkan tabel hasil uji Bonferroni, diketahui bahwa tidak terdapat perbedaan ratarata (mean difference) yang signifikan, tingkat solvabilitas dana tabarru' di antara perusahaan asuransi syariah. Sedangkan dalam tabel yang merupakan hasil Uji Tukey HSD diketahui bahwa terdapat perbedaan rata-rata dana tabarru' yang signifikan di antara perusahaan tersebut AMN dan SKI. Oleh karena itu dalam penelitian ini, significance level yang awalnya 5\% diubah menjadi $10 \%$, dan hasil dari perubahan tersebut dalam dilihat dalam tabel 8 .

Tabel 8. Hasil Uji Tukey HSD

\begin{tabular}{ccccc}
\hline Perusahaan & Terhadap Perusahaan & Mean Difference & Sig & Keputusan \\
\hline AMN & TKF & 0,091 & 0,997 & Tidak terdapat perbedaan \\
\hline & AGA & 0,421 & 0,816 & Tidak terdapat perbedaan \\
\hline TKF & SKI & 1,356 & $0,047^{*}$ & terdapat perbedaan \\
\hline & AMN & $-0,091$ & 0,997 & Tidak terdapat perbedaan \\
\hline AGA & AGA & 0,330 & 0,901 & Tidak terdapat perbedaan \\
\hline & SKI & 1,2645 & $\left.0,070^{*}\right)$ & Tidak terdapat perbedaan \\
\hline & AMN & $-0,421$ & 0,816 & Tidak terdapat perbedaan \\
\hline SKI & TKF & $-0,330$ & 0,901 & Tidak terdapat perbedaan \\
\hline & SKI & 0,934 & 0,241 & Tidak terdapat perbedaan \\
\hline & AMN & $-1,356$ & $\left.0,047^{*}\right)$ & terdapat perbedaan \\
\hline & TKF & $-1,264$ & $0,070^{*}$ & Tidak terdapat perbedaan \\
\hline
\end{tabular}

Sumber: Data hasil SPSS diolah

Hasil Uji Tukey mendukung hasil uji ANOVA yang menyatakan bahwa terdapat perbedaan mean yang signifikan dalam dana tabarru' perusahaan asuransi jiwa syariah di Indonesia. Perbedaan yang signifikan tersebut ada pada perusahaan AMN dan SKI.

Uji Tukey juga memberikan hasil perusahaan asuransi jiwa syariah yang memiliki perbedaan mean yang tidak signifikan atau homogeneous subsets sebagaimana tertera dalam berikut : 
Tabel 9. Homogeneous Subsets

\begin{tabular}{ccccc}
\hline & \multirow{2}{*}{ Perusahaan Asuransi Jiwa Syariah } & N & \multicolumn{2}{c}{ Subsets for alpha = 5\% } \\
\cline { 3 - 5 } Tukey HSD & & \multicolumn{2}{c}{1} & 2 \\
\hline & SKI & 6 & 0,7433 & \\
\hline AGA & 6 & 1,6777 & 1,6777 \\
\hline TKF & 6 & 2,0078 & 2,0078 \\
\hline AMN & 6 & & 2,0995 \\
\hline Sig & & 0,070 & 0,816 \\
\hline
\end{tabular}

Sumber: Data hasil SPSS diolah

Berdasarkan tabel homogeneous subset, kolom subsets 1 diketahui bahwa perusahaan asuransi jiwa syariah SKI, AGA, TKF memiliki perbedaan mean dana tabarru' yang tidak signifikan antara satu dengan yang lainnya. Begitu pula pada kolom subsets 2, perusahaan asuransi jiwa syariah AGA, TKF, AMN memiliki perbedaan mean dana tabarru' yang tidak signifikan antara satu dengan yang lainnya.

\section{PENUTUP}

Agar terhindar dari risiko insolvency, perusahaan asuransi jiwa syariah harus menjaga solvabilitas mereka, terutama pada rasio solvabilitas dana tabarru' karena dana tabarru' adalah dana peserta asuransi yang sewaktu-waktu akan diminta dalam bentuk klaim asuransi. tujuan penelitian ini adalah untuk menguji perbedaan tingkat solvabilitas dana tabarru' di antara perusahaan asuransi jiwa syariah yang ada di Indonesia. Hasil penelitian ini menunjukkan bahwa terdapat perbedaan mean yang signifikan pada dana tabarru' perusahaan asuransi jiwa syariah di Indonesia. Pada uji post hoc benferroni tidak terlihat perbedaan mean tingkat solvabilitas dana tabarru' yang signifikan di antara perusahaan tersebut. Namun jika dilihat dari uji post hoc Tukey HSD terlihat bahwa tingkat solvabilitas dana tabarru' perusahaan AMN berbeda signifikan dengan tingkat solvabilitas dana tabarru' perusahaan SKI.

Penelitian ini hanya dilakukan pada perusahaan asuransi jiwa syariah yang full fledge sehingga sampel pada penelitian ini sangatlah sedikit, sedangkan usaha asuransi jiwa syariah di Indonesia masih banyak yang berbentuk unit usaha syariah dari perusahaan asuransi jiwa konvensional. Sehingga hasil penelitian ini tidak bisa mewakili usaha asuransi jiwa syariah yang masih berbentuk Unit Usaha Syariah (UUS).

Penelitian selanjutnya diharapkan dapat memperluas objek penelitian dengan cara mengubah objek penelitian menjadi UUS ataupun menambah objek penelitian menjadi gabungan full fledge dan UUS sehingga hasil penelitian selanjutnya lebih mencerminkan tingkat solvabilitas semua bentuk usaha asuransi jiwa syariah di Indonesia. Selain itu penelitian ini hanya menguji pada dana tabarru' padahal tingkat solvabilitas yang disarankan dalam POJK No. 72/POJK.05/2015 adalah dana tabarru' dan dana perusahaan. Dengan demikian informasi mengenai tingkat solvabilitas pun menjadi lebih komprehensif, sehingga para stakeholders bisa mengambil keputusan secara lebih valid.

\section{DAFTAR PUSTAKA}

Ambarwati, S., \& Hasib, F. F. (2018). Pengaruh Ukuran Perusahaan, Hasil Investasi, Dan Profitabilitas Terhadap Solvabilitas Asuransi Syariah Di Indonesia Periode 2012-2016. Jurnal Ekonomi dan Bisnis Islam, Vol. 4, No. 2, Juni-Desember 2018, 91-102.

Ananta, Y. (2019, Juli 8). Pertumbuhan Industri Asuransi Lesu, Apa Penyebabnya? Retrieved from CNBC Indonesia: https://www.cnbcindonesia.com/investment/2019070814381121-83378/pertumbuhan-industri-asuransi-lesu-apa-penyebabnya

Asmara, C. G. (2019, November 18). Istana Ogah Ikut-Ikutan soal Kasus Asuransi Jiwasraya. Retrieved from CNBC Indonesia: 
https://www.cnbcindonesia.com/news/20191118125846-4-115992/istana-ogah-ikutikutan-soal-kasus-asuransi-jiwasraya

Bakrie, M. A. (2015, November 28). Solvabilitas. Retrieved from Kompasiana: https://www.kompasiana.com/miabakrie/5658ef2a1dafbddf0d32d7b7/solvabilitas?pag $\mathrm{e}=$ all

Cermati.com. (2016, Mei 1). Perkembangan Perusahaan Asuransi di Indonesia. Retrieved from cermati.com: https://www.cermati.com/artikel/perkembangan-perusahaanasuransi-di-indonesia

CNN Indonesia. (2019, Mei 18). Industri Asuransi Syariah Optimistis Aset Tumbuh 14,76 Persen. Retrieved from CNN Indonesia: https://www.cnnindonesia.com/ekonomi/20190517200737-78-395891/industriasuransi-syariah-optimistis-aset-tumbuh-1476-persen

Ghozali, I. (2018). Aplikasi Analisis Multivariate Dengan Program IBM SPSS 25. Semarang: Badan Penerbit Universitas Diponegoro

Harahap, S. S. (2013). Analisis Kritis atas Laporan Keuangan. Jakarta: Raja Grafindo Persada.

Hidayat, A. (2017, September 18). Uji ANOVA - One Way Anova dalam SPSS. Retrieved from Statistikian: https://www.statistikian.com/2012/11/one-way-anova-dalamspss.html/amp

Ilhama, C. C., \& Abdullah, M. F. (2018). Analisis Pengaruh Profitabilitas, Suku Bunga, Likuiditas, Dan Solvabilitas Terhadap Premi Bruto Asuransi Di Indonesia Pada Tahun 2012-2016. Jurnal Ilmu Ekonomi Vol 2 Jilid 1/Tahun 2018, 104-118.

Kasmir. (2013). Analisis Laporan Keuangan. Jakarta: Raja Grafindo Persada.

Kompas.com. (2019, Juni 28). Keuangan AJB Bumiputera Negatif Rp 20 Triliun, Ini Kata OJK. Retrieved from Kompas:

https://money.kompas.com/read/2019/06/28/054800026/keuangan-ajb-bumiputeranegatif-rp-20-triliun-ini-kata-ojk?page $=$ all

kontan.co.id. (2018, Juli 9). Premi asuransi jiwa syariah melejit 40\% sampai Mei 2018.

Retrieved from kontan.co.id: https://keuangan.kontan.co.id/news/premi-asuransi-jiwasyariah-melejit-40-sampai-mei-2018

OJK. (2016, Februari 19). Daftar Perusahaan Asuransi Umum, Jiwa dan Reasuransi dengan Prinsip Syariah. Retrieved from Otoritas Jasa Keuangan (OJK): https://www.ojk.go.id/id/kanal/iknb/berita-dan-kegiatan/publikasi/Pages/DaftarPerusahaan-Asuransi-Umum,-Jiwa-dan-Reasuransi-dengan-Prinsip-Syariah.aspx

Republik Indonesia. (2014). UU No. 40 Tahun 2014 Tentang Perasuransian.

Utami, E. P., \& Khoiruddin, M. (2016). Pengaruh Rasio Keuangan Early Warning System Terhadap Tingkat Solvabilitas Perusahaan Asuransi Jiwa Syariah Periode 2010-2013. Management Analysis Journal 5 (1) (2016), 55-62. 